\title{
Beta-1,4-Galactosyltransferase 6
}

National Cancer Institute

\section{Source}

National Cancer Institute. Beta-1,4-Galactosyltransferase 6. NCI Thesaurus. Code C103939.

Beta-1,4-galactosyltransferase 6 (382 aa, $\sim 45 \mathrm{kDa}$ ) is encoded by the human B4GALT 6 gene. This protein plays a role in the glycosylation of ceramides. 